\title{
ガラスびんの耐衝撃強度
}

\author{
横倉修一 \\ （麒麟麦酒(株）富田製壜工場）
}

ガラス円管及びびん試験体について，スチールボールによる落球衝撃を与え，試験体の内，外表 面に発生するひずみ（円周方向）分布をストレインゲージにより測定し，スチールボールの衝撃エ ネルギー，試験体の肉厚並びに発生したびず量の関係を定量的に検討し，それと並行して試験体 に同じく点荷重（静荷重）を加えた場合に発生するひずみ分布之の比較検討を行った.

また市場で 7 10 年間使用されたびんを試験体として, 表面傷が集中的に発生している円筒部(外 表面）に同様の落球衝撃を与えて破壊実験を行った。

これらの実験から以下のような知見が得られた。

1. 衝撃時に発生するひずみ分布

i）試験体内表面の場合

発生した引っ張りひずみは衝撃点直下で最大を示し，それから離れるにつれて急激に減少した。ま たその最大値と衝撃エネルギーの間には両対数で直線関係が認められた.

ii）試験体外表面の場合

発生した引っ張りひずみは試験体の肉厚に応じて, 衝撃点から円周方向に $30^{\circ} \sim 60^{\circ}$ (ずれ角度) 離 れた位置に最大值が認められ，本試料びん（肉厚，約 $4 \mathrm{~mm}$ ) の場合では衝撃点からのずれ角度 $50^{\circ}$ 近傍に引っ張りひずみのピークが認められ，外部衝撃による典型的なびんの破壊パターンであ る“ヒンジ割れ” (Hinge fracture) の場合の破壊起点とよく一致した.

2. 試験びんの耐衝撃強度

スチールボールの質量, 衝撃速度並びに衝撃エネルギーとびんの耐衝撃強度の関係について検討 を行った結果，(1)式のような関係式が得られた。

$$
m \cdot V^{2.54}=C
$$

(ここで, $m:$ スチールボールの質量, $V:$ 衝撃速度, $C:$ 定数である.)

また衝撃の負荷速度とびんの破壊強度の関係につき検討を行い, Charles, Evansらにより導か れた(2)式から, 疲労定数, $n \doteqdot 18$ が得られた。

$$
\sigma=\beta \cdot \dot{\sigma}^{\frac{1}{n+1}}
$$

(ここで, $\sigma:$ 破壊応力, $\dot{\sigma}:$ 荷重の負荷速度, $\beta:$ 定数, $n:$ 疲労定数である.)

(1983 年 10 月 3 日受付)

\section{Impact Strength of Glass Containers}

\author{
Shuichi YOKOKURA \\ (Tonda Bottle-Manufacturing Plant, Kirin Brewery Co., Ltd. \\ 4473-4, Ooaza-Tonda, Shin-Nanyou-shi, Yamaguchi 746
}

Characteristics of impact strength of glass containers were investigated, by measuring the extent and distributions of flexure and hinge strains on the surface of glass cylinders and abused sample bottles at the moment of impact by ball-drop testing. The results obtained are summarized as follows :

1) Strain distributions which develop on impact: In the case of flexure strain, a linear relationship was found between impact energy and circumferential flexure strain on the internal surface just under the impact point in logarithmical unit. In the case of hinge strain, the position, where the circumferential hinge strain on the external surface was peaked, was dependent on 
the thickness of the cylindrical sidewall. For instance, at the thickness of ca. $4 \mathrm{~mm}$, the circumferential hinge strain was found to be peaked at ca. $50^{\circ}$ round the bottle from the impact point.

2) Fracture strength of bottles : The relationship between mass and impact velocity of a steel ball at the moment of bottle breakage was investigated, and the following formula was obtained: $m \cdot V^{2.54}=C$

where, $m:$ mass of a steel ball, $V:$ impact velocity, $C:$ constant.

Further, the elasto-mechanical characteristics of this test were compared with that of a static load test.

[Received October 3, 1983]

Key-words : Glass, Bottle, Impact, Strength, Ball-drop test, Strain, Stress

\section{1. 緒言}

リターナブルびん（回収，再使用可能）の強度特性に ついては, 従来から業界で内圧試験, 熱衝撃試験等が中 心に検討され実施されているが，実際に市場でびんが破 損する主な原因は何らかの外部からの衝撃が加わった場 合が圧倒的に多く，内圧あるいは熱衝撃が直接的な原因 となることは必ずしも多くない，ところでこの衝撃に関 する研究は，その大半が断片的な検討に終わっている観 があり,びんの耐衝撃強度に関する総合的な研究は行わ れなかった

そこで本研究においては試験体としでガラスびん及び ガラス円管（形状を単純化する理由から）の2種類を用 い，衝撃に関する基本的な検討をした。

まず衝撃体として，スチールボールを選び，その自然 落下により試験体に衝撃を加え, 試験体の内, 外表面に 発生するひずみをストレインゲージにより測定した。そ れと並行して試験体に点荷重（静荷重）を加えて同様の 測定を行い，動的並びに静的荷重負荷に関する比較検討 を行った.

ところでびんが衝撃により破壊する場合は落下，転倒 等により硬い床面に衝突するなどのケースが多いと考え られるが，破壊の起点を調査してみると，びんの特定の 位置（表面傷が集中的に発生している円筒部，外表面） に集中していることが分る．また破壊パターンをみると “ヒンジ割れ”（衝撃点からびんの円周方向に沿って $40^{\circ} \sim 60^{\circ}$ 程度離れた外表面のヒンジ (Hinge) 部で引っ 張りひずみが最大を示す位置に破壊起点が発生すること を特徴亡する破壊パターン（21,91,101 12)がその大半を占め ており，その破壊状態を観察すると，破壊起点からの割 れ目が上下方向に進展しているケースが圧倒的に多い. また衝撃時に発生する引つ張りひずみ量をみると, 円周 方向の方が垂直方向よりも明らかに大きいため ${ }^{11,12)}$, 本 研究においては円周方向に発生するひずみに限定して検 討することにした。

またガラス円管については市場に出回っているガラス びんの肉厚がワンウェイ（1 回使用後, 廃棄), リ夕ー ナブルを含めて 2〜 $5 \mathrm{~mm}$ 程度が大半を占めているため, 肉厚として $1.6 \sim 6.8 \mathrm{~mm}$ の範囲に限定した. 外径につ
いては70〜80 $\mathrm{mm}$ のびんが圧倒的に多いため, 今回は $75 \mathrm{~mm}$ を中心に検討することにした。

\section{2. 実験方法}

\section{1 ガラス試験体の概要}

ガラス試験体としては円管及びびんを用いた。円管と しては両端開きで, 管長 $400 \mathrm{~mm}$, 外径 $33 \sim 75 \mathrm{~mm}$, 肉 厚 1.6〜6.8 mm の範囲とし, 落球時の衝撃点の位置は 円管中央部とした，試料びんとしては我が国で，広く使 用されているびん種を選んだ。びん形状を図1に示す. またびんの諸元は以下のとおりである. 重量 $575 \mathrm{~g}$, 内 容量 $658 \mathrm{~cm}^{3}$, 高さ $289 \mathrm{~mm}$, 胴径 $75 \mathrm{~mm}$, 肉厚, 約 $4 \mathrm{~mm}$. この試料びんは市場で 7〜10 年間使用したものに限定し た. その理由としては表面傷が一様に発生しており, 強 度のばらつきが比較的小さく, 安定しているためであ $ろ^{13)}$. 落球時の衝撃点は表面傷が集中的に発生している 円筒部（びん底より $140 \mathrm{~mm}$ 高さの位置）とした。なお ガラス円管並びに試料びんの化学組成を表 1 に示す.

\section{2 試験方法}

\section{（ｉ）落球衝撃の場合}

球径の異なるスチールボールを一律に高さ $100 \mathrm{~mm}$ よ り鉄製台座上に水平に置かれたガラス試験体の所定位置 へ自然落下させて点衝撃を与え, 試験体の内, 外表面に

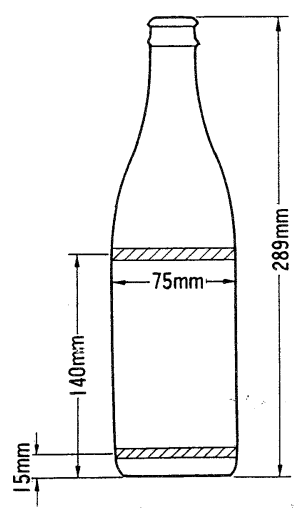

Fig. 1. Schematic illustration of a test bottle.

1) Inner volume : $658 \mathrm{~cm}^{3}$, Weight $: 575 \mathrm{~g}$

2) The two oblique areas illustrated incur heavy abrasion (Wall thickness, ca. $4 \mathrm{~mm}$ ). 
Table 1. Chemical compositions (wt \%) of a glass cylinder and a bottle.

\begin{tabular}{|l|cc|}
\hline Composition & Cylinder & Bottle \\
\hline $\mathrm{SiO}_{2}$ & 71.2 & 70.6 \\
$\mathrm{~B}_{2} \mathrm{O}_{3}$ & 9.4 & \\
$\mathrm{Al}_{2} \mathrm{O}_{3}$ & 1.4 & 2.0 \\
$\mathrm{~K}_{2} \mathrm{O}$ & & 1.2 \\
$\mathrm{Na}_{2} \mathrm{O}$ & 8.7 & 14.7 \\
$\mathrm{CaO}$ & 2.5 & 9.6 \\
$\mathrm{MgO}$ & 3.3 & 1.7 \\
$\mathrm{ZnO}$ & 3.1 & \\
$\mathrm{BaO}$ & & 0.06 \\
$\mathrm{MnO}$ & & 0.12 \\
$\mathrm{Fe}_{2} \mathrm{O}_{3}$ & & 0.17 \\
$\mathrm{MiO}_{2}$ & & 0.07 \\
$\mathrm{SO}_{3}$ & & 0.09 \\
\hline
\end{tabular}

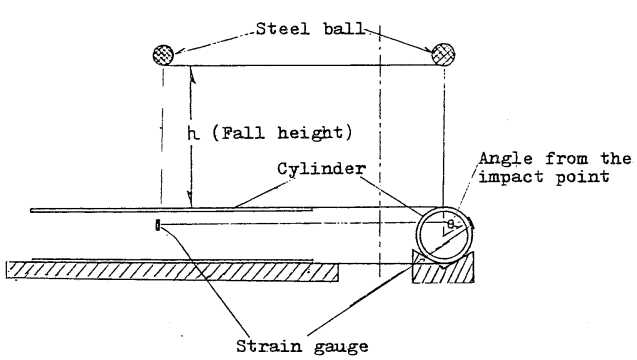

Fig. 2. Schematic diagram of a ball-drop test.

発生するひずみ(円周方向)を衝撃点から円周方向に沿っ て測定した（図２参照）。なおひずみの測定はストレイ ンゲージ (共和電業社製, $\mathrm{KFC}-03-\mathrm{C} 1-11$, ゲージ抵 抗 $120 \Omega$,ゲージ・ファクター 2.0 ,ゲージ長さ $0.3 \mathrm{~mm}$ ) を用い, 動ひずみ計 (共和電業社製, CDV-110 A) から, トランジェント・メモリ (岩崎通信機社製, SS-5025 型) を通し, オシロスコープに振動波形を出した。衝撃直後 に試験体に発生する振動波の最大振幅を求めた。

\section{（ii）点荷重の場合}

材料試験機（島津製作所製，IS-5000）を用いて，鉄 製台座上に水平に置かれたガラス試験体の所定位置にス チールボールを介して点荷重を加え, 発生する円周方向 のひずみを同様にストレインゲージを用いて, 荷重点か ら円周方向に沿って測定した14).

\section{3. 結果並びに考察}

\section{1 衝撃時及び静的点荷重時に発生するひずみ分布}

\section{（ｉ）円管の内表面の場合}

ガラス円管として肉厚の異なる 3 種類（肉厚 $2.2 \mathrm{~mm}$, $4.3 \mathrm{~mm}$ 及び $6.8 \mathrm{~mm}$ ，外径を一律に $75 \mathrm{~mm}$ ) につき, 球径の異なるスチールボールを一律に高さ $100 \mathrm{~mm}$ より

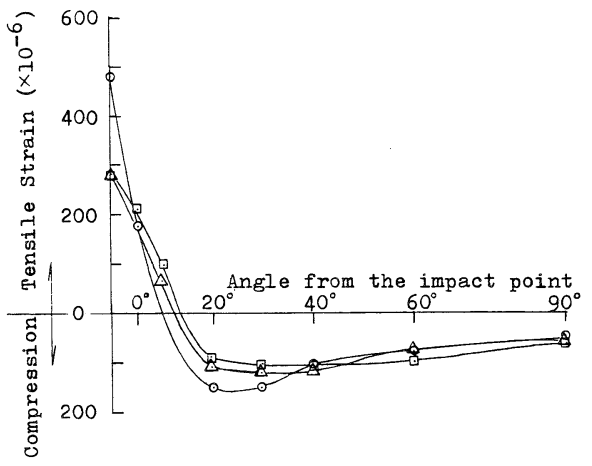

Fig. 3. Strain distributions developed on the internal surfaces of test cylinders at impact tests.

$\begin{array}{ccc}\begin{array}{c}\text { Wall } \\ \text { thickness }\end{array} & \begin{array}{c}\text { Weight of } \\ \text { steel ball }\end{array} & \begin{array}{c}\text { Fall } \\ \text { height }\end{array} \\ 2.2 \mathrm{~mm} & 2.07 \mathrm{~g} & 100 \mathrm{~mm} \\ 4.5 \mathrm{~mm} & 4.10 \mathrm{~g} & 100 \mathrm{~mm} \\ 6.5 \mathrm{~mm} & 13.70 \mathrm{~g} & 100 \mathrm{~mm}\end{array}$

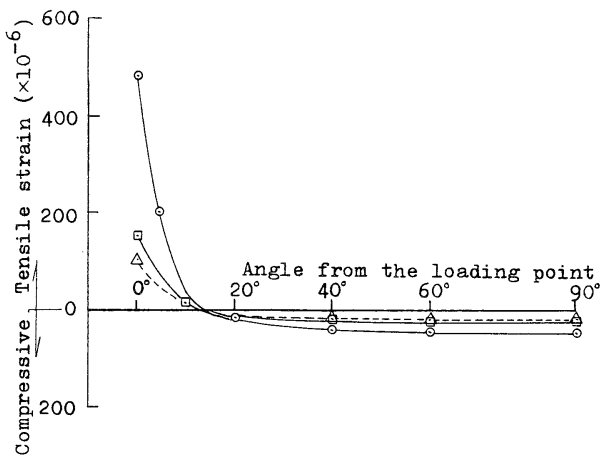

Fig. 4. Strain distributions developed on the internal surfaces of test cylinders at static load tests.

1) Wall thickness : $\bigcirc-2.3 \mathrm{~mm}$,
$\triangle \longrightarrow \triangle .1 \mathrm{~mm}$,
$4.8 \mathrm{~mm}$

2) The value of a load, $10 \mathrm{~kg}$

自然落下させ，発生したひずみを衝撃点直下より円周方 向に沿って, ずれ角度 (衝撃点からずれた角度) $90^{\circ}$ の 範囲にわたり測定した．測定例を図 3 に示す。図 3 から 明らかなように円管内表面に発生したひずみは衝撃点直 下が最大であり，それからずれるに従って急激に低下し， ずれ角度 $10^{\circ} \sim 15^{\circ}$ 近傍でひずみは引っ張りから圧縮へ と変わった。ずれ角度 $15^{\circ}$ 以降の圧縮ひずみ領域ではず れ角度 $20^{\circ} \sim 40^{\circ}$ の近傍にひずみのピークが認められた。

一方点荷重の場合では図 4 から明らかなように, 圧縮 ひずみ領域では明確なピークは認められず, 点衝撃の場 合とはかなり異なったひずみ分布を呈した。

次に衝撃点直下に発生した引つ張りひずみ量(最大值) と落球による衝撃エネルギーの関係を検討してみると, 図 5 から明らかなように両対数で直線関係が認められ た.

一方静的点荷重の場合では図 6 から明らかなように, 


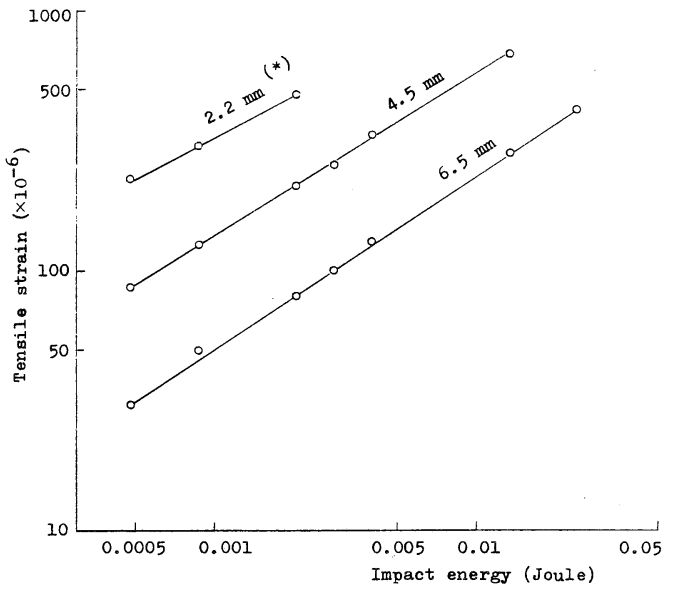

Fig. 5. Relationship between impact energy and maximum tensile strain developed on the internal surface of test cylinders.

* The values in the graph show wall thickness.

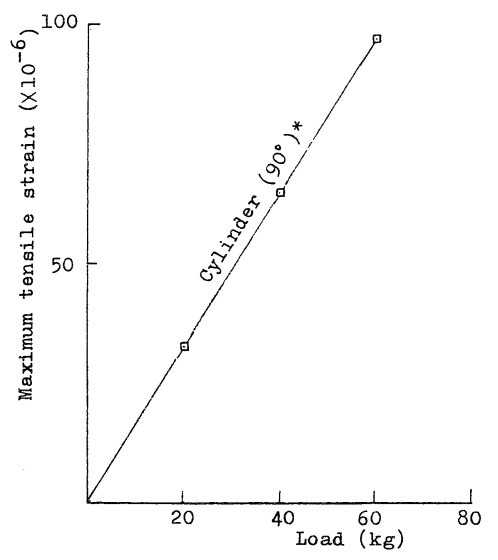

Fig. 6. Relationship between a load and the maximum tensile hinge strain developed at the external surface of a test cylinder.

* Angle from a loading point

Wall thickness : $4.5 \mathrm{~mm}$

荷重量と荷重点直下に発生した引つ張りひずみ量（最大 值）の間には直線関係が認められた。

\section{（ii） 円管の外表面の場合}

ガラス円管として肉厚の異なる 4 種類（肉厚 $1.6 \mathrm{~mm}$, $1.9 \mathrm{~mm}, 4.3 \mathrm{~mm}$ 及び $6.7 \mathrm{~mm}$ ，外径は一律に $75 \mathrm{~mm}$ ) につき，球径の異なるスチールボールを一律に高さ 100 $\mathrm{mm}$ より自然落下させて, 発生するひずみ量を衝撃点よ り円周方向に沿って，ずれ角度 $90^{\circ}$ の範囲にわたって測 定し，引つ張りひずみがピークを示すヒンジ部年 ${ }^{121}$ の 位置について検討を行った。 その結果を図7に示す.図 7 から明らかなようにひずみ量が最大を示す位置（ずれ 角度）は円管の肉厚に依存しており，肉厚の増加ととも にずれ角度が $30^{\circ}$ 近傍から $60^{\circ}$ 近傍へと移行する傾向が 認められた。したがってびんに“ヒンジ割れ”が発生し

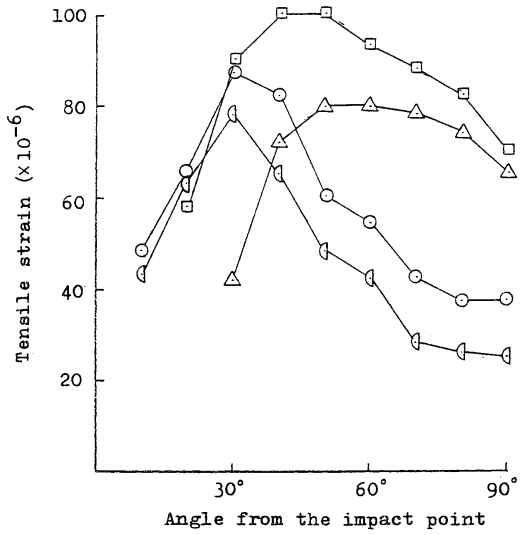

Fig. 7. Distribution of tensile strain developed on the external surface of test cylinders at ball-drop tests.

Wall thickness : $\bigcirc-\bigcirc 1.6 \mathrm{~mm}, \bigcirc-\bigcirc 1.9 \mathrm{~mm}$, $\square-\square \quad 4.3 \mathrm{~mm}, \triangle-\triangle \quad 6.7 \mathrm{~mm}$

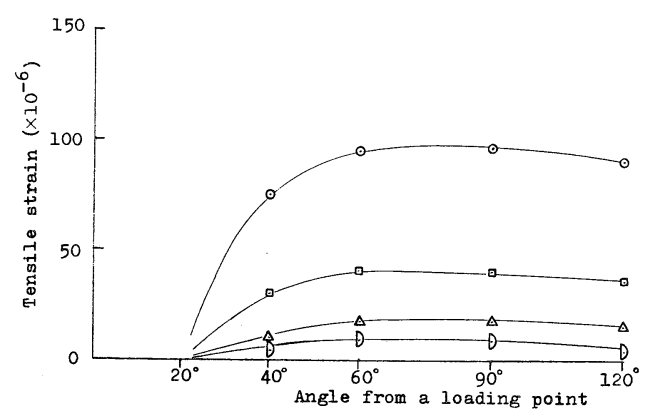

Fig. 8. Strain distributions developed on the external surface of test cylinders at the static load test.

1) Wall thickness : $\bigcirc-\bigcirc 1.5 \mathrm{~mm}$,
$2.3 \mathrm{~mm}$,
$\triangle 4.1 \mathrm{~mm}, \mathrm{D} \longrightarrow \mathrm{D}$
$6.8 \mathrm{~mm}$

2) The value of a static load : $10 \mathrm{~kg}$

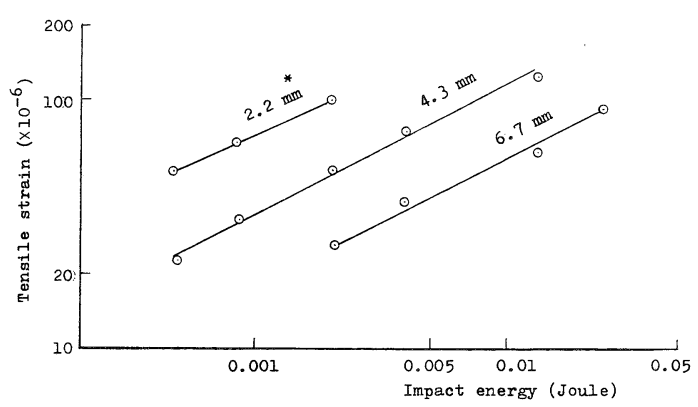

Fig. 9. Relationship between impact evergy and maximum tensile strain developed on the outer surface of test cylinders at the impact test.

1) * The values show wall thickness

2) Fall height of steel balls : $100 \mathrm{~mm}$

た場合の破壊起点の位置は一定でなく，びん円筒部の肉 厚に依存すると考えてよい.

また発生した引つ張りひずみの最大值と衝撃エネル ギーの関係をみると，図 9 から明らかなように両対数で 直線関係が認められた。 


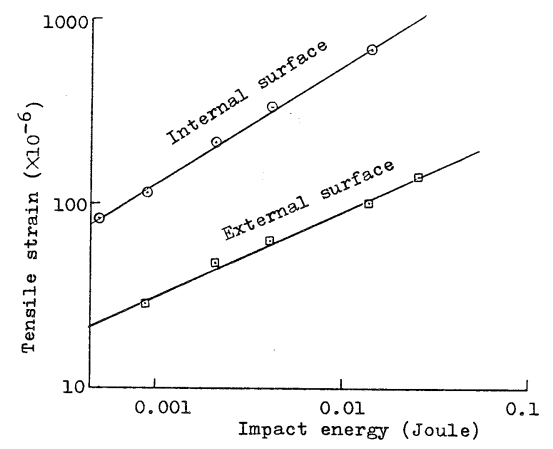

Fig. 10. Relationship between impact energy and tensile strain developed on the surface of a test bottle at the impact test.

1) Wall thickness, $4.3 \mathrm{~mm}$

2) Impact point : Cylindrical part, $140 \mathrm{~mm}$ high from the bottom

3) Fall height of steel balls : $100 \mathrm{~mm}$

一方静的点荷重の場合では図 8 に示すように, 引つ張 りひずみが最大を示すヒンジ部の位置は明確には認めら れず，また肉厚にほとんど関係なく，ずれ角度 $60^{\circ} \sim 90^{\circ}$ 近傍になだらかなピークが認められ，点衝撃の場合とは かなり異なった傾向が認められた。

\section{（iii） 試料びんの場合}

試料びんを鉄製台座上に水平に置き，びん底より 140 $\mathrm{mm}$ 高さの円筒部に落球衝撃を与え, 衝撃点直下の内表 面及び衝撃点より円周方向にずれ角度 $50^{\circ}$ の外表面

(引っ張りひずみが最大を示す位置) に発生したひずみ 量を測定した.

測定結果を図 10 に示す。図 10 から明らかなように内 表面 (衝撃点直下) に発生した引っ張りひずみ量はガラ 不円管の場合とほとんど同じ值を示したが，一方外表面 に発生した引っ張りひずみ量はガラス円管に比べて若干 低い傾向が認められた。この原因はびん首部及び底部の 端末条件の影響と考えられる。

\section{2 試料びんの破壊実験}

\section{（）衝撃エネルギーとびん強度の関係}

市場で 7 10 年間使用され, 表面傷が多数発生してい る試料びんについて, 落球衝撃による破壊実験を行った. 試料びんを鉄製の台座上に水平に置き，びん底から 140 $\mathrm{mm}$ の高さにある円筒部で表面傷が集中的に発生してお り, 破壊起点となりやすい位置(図 1 参照)を対象として, 所定重量のスチールボールを自然落下させて衝撃を与 え，落下高さを段階的に上昇させていくプログレッシー ブ法による破壊実験を行った。実験結果を図 11 に示す. またびん破壊時のスチールボールの質量と衝撃速度の関 係を図 12 に示す。図 12 から明らかなように本実験にお けるスチールボールの質量及び衝撃速度の範囲において は両対数で直線関係が認められ, 以下のような実験式成 立した。

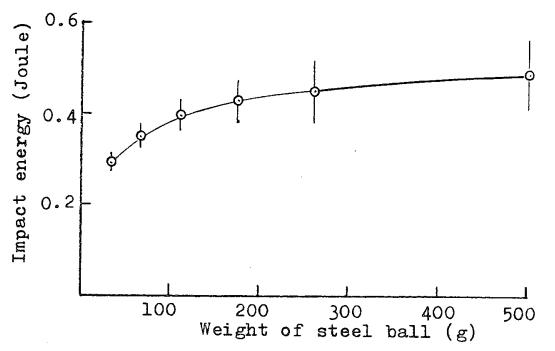

Fig. 11. Relationship between impact energy and the weight of steel balls at the bottle breakage.

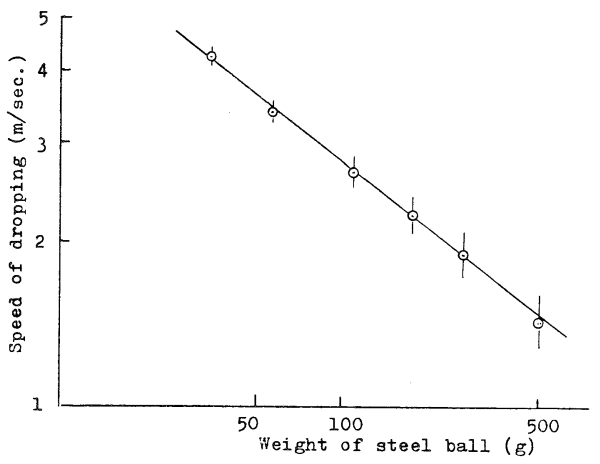

Fig. 12. Relationship between the speed of dropping and the weight of steel balls at the bottle breakage.
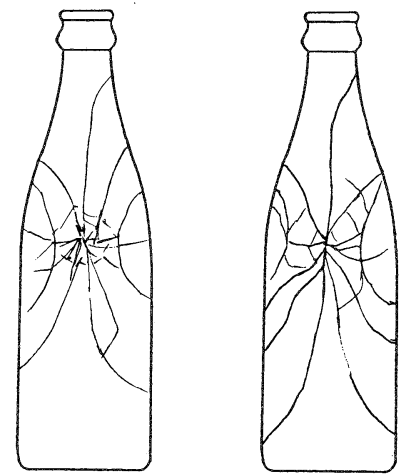

Fig. 13. Schematic illustration of a hinge breakage of test bottles.

$$
m \cdot V^{2.54}=C
$$

ここで, $m$ : スチールボールの質量, $V$ : 衝撃時の落球 速度 $(\mathrm{m} / \mathrm{s})$.

したがって落球衝撃によるびんの破壊は単に衝撃エネ ルギー量だけでは一律に把握し得ないことが分った。

\section{(ii ) 衝撃速度とびん強度の関係}

落球衝撃による試料びんの破壊状態を観察すると, 図 13 に示すような特徵的な破壊パターンが一様に認めら れ, 破壊起点はヒンジ・ストレインが最大となる外表面 (衝撃点より円周方向に沿って $40^{\circ} \sim 60^{\circ}$ ずれた位置) にほぼ一致した ${ }^{9 !}$. そこで試料びん破壊時のヒンジ・ス トレイン量について検討を行った. まず本実験における 
スチールボールの落下高さは一律に $100 \mathrm{~mm}$ に設定して おり，それに対応する落球速度， $V=1.4 \mathrm{~m} / \mathrm{s}$ における スチールボール質量, $m$ は図 12 から $500 \mathrm{~g}$ が読み取れ る.したがって衝撃エネルギーは約 0.49 Joule $\left(=\frac{1}{2} m\right.$. $\left.V^{2}\right)$ である.したがってびん外表面のヒンジ部に発生す る最大引つ張りひずみ量は図 10 から約 $550 \times 10^{-6}$ が読 み取れる。

次にスチールボールが試料びんに衝突し, 衝撃エネル ギーを伝達する時間（本報告では仮に衝撃持続時間之 呼ぶことにする) については柴田ら ${ }^{8)}$ の研究報告があり, それによれば，まず衝撃点直下の内表面の場合に衝撃持 続時間とスチールボール質量の関係は図 14 から明らか なように両対数で直線関係が認められており，また外表 面（引っ張りひずみが最大となるヒンジ位置）の場合で は，衝撃持続時間は内表面直下の場合に比べて若干短い が，同じくスチールボール質量との間に両対数で直線関 係が認められており ${ }^{21)}$ ，この関係を用いてスチールボー ル $500 \mathrm{~g}$ に対応する衝撃持続時間を求めると約 $310 \mu \mathrm{s}$, が得られた。この值から衝撃時のヒンジ・ストレインの 上昇速度を計算すると, $550 \times 10^{-6} / \frac{310 \times 10^{-6}}{2} \fallingdotseq 3.5$ $\left(\mathrm{s}^{-1}\right)$ が得られる.この結果を前報 ${ }^{14)}$ で報告した(荷重 速度-びん強度) 関係図にプロットしてみると, 図 15 か

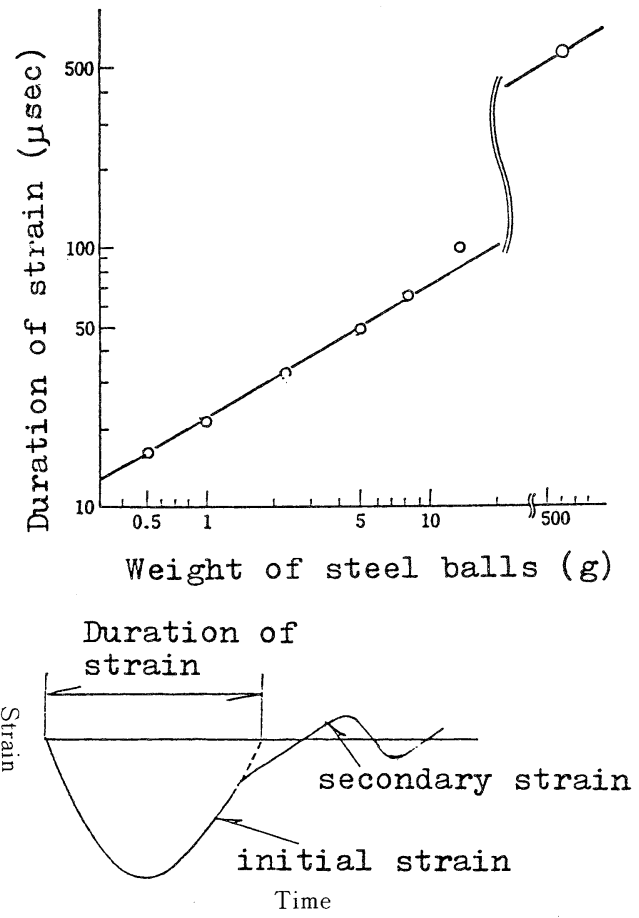

Fig. 14. Relationship between duration of strain developed on the internal surface of a test bottle and the weight of steel balls at an impact test.

1) These data were cited from Shibata's report ${ }^{8)}$

2) Duration of strain is illustrated in the following figure
ら明らかなようにほぼ直線上に乗ることが分り,

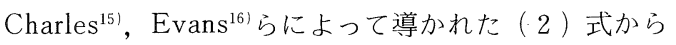
$n \fallingdotseq 18$ なる值が得られ, Ritter ら ${ }^{17)}$, Chandan ら ${ }^{18)}$ のソー ダ・石灰ガラスにおける実験結果とほぼ一致した。

$$
\sigma=\beta \cdot \dot{\sigma}^{\frac{1}{n+1}}
$$

ここで, $\sigma$ : 破壊応力, $\dot{\sigma}:$ 応力の負荷速度, $\beta$ : 定数, $n:$ 疲労定数.

（ii）びんの内, 外表面傷の深さと破壊起点の関係

落球衝撃により破壊起点となったびん円筒部（びん底 から $140 \mathrm{~mm}$ 高さの位置) の外表面に発生している表面 傷の最大深さを横倉ら ${ }^{19)}$ の方法により測定してみると, 約 $0.6 \sim 0.7 \mathrm{~mm}$ に分布していることが分った。

そこでいま表面傷の深さと, それを破壊起点とする破 壊応力の関係につき破壊力学的に検討してみる. まず限 界応力拡大係数, $K_{\mathrm{Ic}}$ は以下のように表される.

外表面の場合, $K_{\mathrm{Ic}}=\sigma_{0} \sqrt{\pi \cdot C_{0}} \cdot Y_{0}$

内表面の場合, $K_{\mathrm{IC}}=\sigma_{\mathrm{i}} \sqrt{\pi \cdot C_{\mathrm{i}}} \cdot Y_{\mathrm{i}}$

ここで $\sigma$ : 破壊応力, $C$ : 表面傷の深さ, $Y$ : クラック に関する形状係数.

ところで $Y$ は点荷重, 点衝撃ともに曲げ応力に関す る形状係数と考えてよいから, 以下の式で示される ${ }^{201}$.

$$
Y=1.122-140 \xi+7.33 \xi^{2}-13.08 \xi^{3}+14.0 \xi^{4}
$$

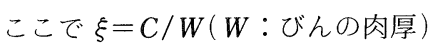

いま $C_{0}=0.7 \mathrm{~mm}$ とすると, $W=4 \mathrm{~mm}$ であるから， 外表面の場合は $\xi=0.7 / 4$, したがって $Y_{0} \doteqdot 1.04$ となる.

一方内表面の場合は $C_{\mathrm{i}} \ll C_{0}$ 亡考えられるから，した がって $Y_{\mathrm{i}} \doteqdot 1.12$ と考えてよい.

そこでびん破壊時の衝撃エネルギー0.49 Jouleにお けるびんの内, 外表面に発生する引つ張りひずみ量は図 10 から $6600 \times 10^{-6}$ 及び $550 \times 10^{-6}$ と推定されるから， 発生する引っ張り応力は以下のように示される.

$$
\begin{aligned}
& \sigma_{0}=550 \times 10^{-6} \cdot E(E: \text { ヤング率 }) \\
& \sigma_{\mathrm{i}}=6600 \times 10^{-6} \cdot E
\end{aligned}
$$

ところで衝撃時にもし内，外表面が同時に破壊起点に なるとすれば, 内表面傷の深さ $C_{\mathrm{i}}$ は $(3)$ 式, 及び $(4)$

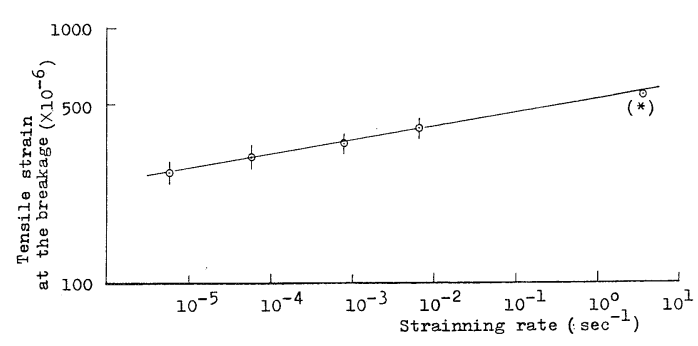

Fig. 15. Relationship between a strain rate and a strain value at the bottle breakage. * Fall height of a steel ball : $100 \mathrm{~mm}$ 
式から以下のように示される。

$$
C_{\mathrm{i}}=C_{0}\left(\frac{\sigma_{0}}{\sigma_{\mathrm{i}}}\right)^{2} \cdot\left(\frac{Y_{0}}{Y_{\mathrm{i}}}\right)^{2}
$$

これまでに得られた数值を（6）式に代入し， $C_{\mathrm{i}}$ を求 めれば， $C_{\mathrm{i}}=6 \times 10^{-3} \mathrm{~mm}$ なる值が得られた。したがっ て内表面傷の深さが $6 \mu$ 以上であれば，びんの破壊は “ヒンジ割れ”ではなく, 内表面が破壊起点となる“た わみ割れ” (Flexure breakage) になると考えられる.

\section{4. 総 括}

ガラス円管及びびん（市場で 7〜10 年間使用された） を試験体としてスチールボールによる落球衝撃試験を行 い，試験体に発生するひずみ分布をストレインゲージを 用いて測定し，それと並行して試験体に点荷重を加えた 場合のひずみ分布との比較検討を行った。

その結果，試験体内表面に発生した引つ張りひずみの 最大值と衝撃エネルギ一の間にはそれぞれ両対数で直線 関係が認められた。また衝撃時に外表面に発生する引つ 張りひずみが最大を示す位置（ヒンジ部）はずれ角度は 一定ではなく，肉厚に依存することが分った。

次に落球によるびんの破壊実験を行い, スチールボー ルの質量, 落球速度, 衝撃エネルギー, 衝撃持続時間等 とびんの耐衝撃強度の関係につき検討を行った。

その結果，びんの破壊は単に衝撃エネルギ一量だけで は一律に把握し得ず, 本実験条件の範囲においては, $m \cdot V^{2.54}=C(m$ : スチールボールの質量, $V$ : 落球速度,
$C$ : 定数) なる関係が得られた。また衝撃の負荷速度と 耐衝撃強度の関係について Charles や Evansらにより 導かれた式を採用した。疲労定数， $n$ を計算して， $n \doteqdot$ 18 が得られた。

\section{文献}

1) R. N. Haward, J.Soc. Glass Technol., 28, 5-31 (1944).

2) 中山 淳, 旭硝子研究報告, 8, 65-81 (1958).

3) Y. M. Tsai and H. Kolsky, J. Mech. Solids, 15, 263-78 (1967).

4) E. B. Shand, Ceramic Bulletin, 47, 1157-65 (1968).

5) G. Schönbrunn, Glastechn. Ber., 46, 49-58 (1973).

6) R. E. Berger, Am. J. Optom and Physiol Optics, 53, 279-86 (1976).

7) W. H. Duckworth and A.R. Rosenfield, Am. J. Optom and Physiol Optics, 55, 801-06 (1978).

8) M. Shibata and H. Itami, Rept. Res, Lab. Kirin Brewery Co. Ltd., 21, 1-9 (1978).

9）横倉修一, 白倉 昌, 材料科学, 19, 323-29 (1983).

10) R. E. Mould, J. Am. Ceram. Soc., 35, 230-35 (1952).

11) S. M.Budd and W.P.Cornelius, Glass Technol., 17,5459 (1976).

12) S. M. Budd and W. P. Cornelius, Glass Technol., 20, 17073 (1979).

13）横倉修一，筌業，91,429-36（1983）。

14）横倉修一，岡田 稔，窯協，92, 360-65（1984）。

15) R. J. Charles, J. Appl, Phys, , 29, 1657-62 (1958).

16) A. G. Evans, Int. J. Fracture, 10, 251-59 (1974).

17) J.E. Ritter and C. L. Sherburne, J.Am. Ceram. Soc., 54, 601-05 (1971).

18) H. C. Chandan, R. C. Bradt and G. E. Rindone, J. Am. Ceram. Soc, , 61, 207-13 (1978).

19）横倉修一，吉田明輝，窯協，91，196-97（1983）。

20）岡村弘之, “線形破壊力学入門”, 培風館 (1980) p.21718.

21）柴田正敏，土田富士夫，麒麟紀要 (未公開)。 